\title{
'Mycoplasma hominis does not share common risk factors with other genital pathogens': Findings from a South African pregnant cohort
}

\begin{tabular}{|c|c|}
\hline \multicolumn{2}{|c|}{$\begin{array}{l}\text { Authors: } \\
\text { Meleshni Naicker }{ }^{1} \text { (D) } \\
\text { Fazana Dessai }{ }^{1} \text { (D) } \\
\text { Ravesh Singh }{ }^{2} \text { (D) } \\
\text { Nireshni Mitchev }^{2} \text { (D) } \\
\text { Partson Tinarwo }{ }^{3} \text { (D) } \\
\text { Nathlee S. Abbai }{ }^{4} \text { (D) }\end{array}$} \\
\hline \multicolumn{2}{|c|}{$\begin{array}{l}\text { Affiliations: } \\
{ }^{1} \text { School of Clinical Medicine } \\
\text { Laboratory, College of Health } \\
\text { Sciences, University of } \\
\text { KwaZulu-Natal, Durban, } \\
\text { South Africa }\end{array}$} \\
\hline \multicolumn{2}{|c|}{$\begin{array}{l}{ }^{2} \text { Department of Medical } \\
\text { Microbiology, College of } \\
\text { Health Sciences, University } \\
\text { of KwaZulu-Natal, Durban, } \\
\text { South Africa }\end{array}$} \\
\hline \multicolumn{2}{|c|}{$\begin{array}{l}{ }^{3} \text { Department of Biostatistics, } \\
\text { Faculty of Health Sciences, } \\
\text { University of KwaZulu-Natal, } \\
\text { Durban, South Africa }\end{array}$} \\
\hline \multicolumn{2}{|c|}{$\begin{array}{l}{ }^{4} \text { Department of Clinical } \\
\text { Medicine Laboratory, Faculty } \\
\text { of Health Sciences, University } \\
\text { of KwaZulu-Natal, Durban, } \\
\text { South Africa }\end{array}$} \\
\hline \multicolumn{2}{|c|}{$\begin{array}{l}\text { Corresponding author: } \\
\text { Meleshni Naicker, } \\
\text { naickerm4@ukzn.ac.za }\end{array}$} \\
\hline \multicolumn{2}{|c|}{$\begin{array}{l}\text { Dates: } \\
\text { Received: } 15 \text { Apr. } 2020 \\
\text { Accepted: } 09 \text { Mar. } 2021 \\
\text { Published: } 19 \text { May } 2021\end{array}$} \\
\hline \multicolumn{2}{|c|}{ Read online: } \\
\hline 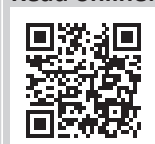 & $\begin{array}{l}\text { Scan this QR } \\
\text { code with your } \\
\text { smart phone or } \\
\text { mobile device } \\
\text { to read online. }\end{array}$ \\
\hline
\end{tabular}

Background: The role of Mycoplasma hominis (M. hominis) as a genital tract pathogen was still debatable. This study identified the risk factors associated with the prevalence of $M$. hominis in South African pregnant women.

Methods: This was a cross-sectional analysis of $n=221$ prenatal patients attending a Durban hospital during November 2017 to April 2018. M. hominis was detected from urine samples using the quantitative polymerase chain reaction. The population characteristics were described using frequencies stratified by the infection status of $M$. hominis. In addition, a univariate analysis was used to assess the relationship between each risk factor and infection status. The analysis further considered logistic regression to assess the influence of these risk factors univariately and in the presence of other factors. The coinfection rate between M. hominis and bacterial vaginosis (BV), Trichomonas vaginalis (T. vaginalis), Mycoplasma genitalium (M. genitalium) and Candida species was also determined. All the tests were conducted at $5 \%$ level of significance.

Results: The prevalence of $M$. hominis in this study population was $48 \%(106 / 221)$. In the univariate analysis, factors significantly associated with $M$. hominis positivity included having past abnormal vaginal discharge $(p=0.037)$, having current abnormal vaginal discharge $(p=0.010)$ and a borderline significance $(p=0.052)$, which were noted for previous pre-term delivery. However, none of these factors were sustained in the multivariate analysis. There was a statistically significant association between $M$. hominis and BV positivity $(p<0.001)$. Similarly, M. hominis and M. genitalium positivity was significant $(p=0.006)$.

Conclusion: This study showed that $M$. hominis does not share common risk factors with known genital tract pathogens in a population of pregnant women and therefore cannot be considered a genital tract pathogen.

Keywords: Mycoplasma hominis; vaginal infections; pregnant women; risk factors ; HIV infection; bacterial vaginosis.

\section{Introduction}

According to the World Health Organization (WHO), there are more than 376 million incidences of sexually transmitted infections (STIs) reported worldwide annually, thus making these infections an important public health concern. ${ }^{1}$ Depending on the causative agent, an STI is usually manifested in a skin lesion, secretion, vaginal discharge, wart or blister. ${ }^{2}$ The vaginal microbiome consists of numerous microorganisms, including members of the class Mollicutes, order Mycoplasmatales (mycoplasmas and ureaplasmas). ${ }^{3}$

Mollicutes are included in STIs, but they are also found in healthy individuals. ${ }^{2}$ The most important Mollicutes colonising the female genital tract are Ureaplasma urealyticum, Ureaplasma parvum, Mycoplasma hominis (M. hominis) and Mycoplasma genitalium (M. genitalium) ${ }^{4}$ Genital mycoplasmas colonise the vaginal tract of up to $80 \%$ of pregnant and non-pregnant women. ${ }^{5}$

Mycoplasma hominis is considered to be an important opportunistic pathogen implicated in urogenital infections and complicated pregnancy outcomes. ${ }^{6}$ These include pelvic inflammatory disease, endometritis, chorioamnionitis and postpartum fever, resulting in complications such as infertility,

How to cite this article: Naicker M, Dessai F, Singh R, Mitchev N, Tinarwo P, Abbai NS. 'Mycoplasma hominis does not share common risk factors with other genital pathogens': Findings from a South African pregnant cohort. S Afr J Infect Dis. 2021;36(1), a207. https://doi. org/10.4102/sajid.v36i1.207

Copyright: @ 2021. The Authors. Licensee: AOSIS. This work is licensed under the Creative Commons Attribution License. 
spontaneous abortion, stillbirth, preterm birth, low birth weight and perinatal mortality. ${ }^{7,8,9,10,11,12}$

An earlier study had provided evidence stating that M. hominis is not a vaginal pathogen in adults. ${ }^{13}$ However, a study published in the same year by Arya et al. referred to $M$. hominis as a vaginal pathogen because of its association with Trichomonas vaginalis (T. vaginalis). ${ }^{14}$ There have been limited studies since 2001, which have contributed to resolving the discordance regarding the role of $M$. hominis as a genital tract pathogen. The aim of the current study was to describe the prevalence and factors associated with $M$. hominis in pregnant women as well as its likelihood of being considered as a genital tract pathogen.

\section{Materials and methods Study setting and population}

This study was a sub-study of a larger study that investigated the laboratory-based diagnosis of vaginal infections in pregnant women from Durban. The larger study included $n=273$ women, 18 years and older from all gestational ages who are willing to provide written informed consent. The study population was recruited from the King Edward VIII hospital in Durban, KwaZulu-Natal between October 2017 and April 2018. All patients were outpatients. There was a $10 \%$ refusal rate by the women during screening. A questionnaire was administered to collect data on the women's demographics, sexual behaviour and clinical information. All interviews were conducted in private, and all study-related information was stored securely. All records and specimens had been identified by study identification numbers only to maintain participant confidentiality.

Only participants who had given written informed consent were included in the study. The study did not collect data on whether the women were experiencing any complications during pregnancy. During the study visit, women were asked to provide self-collected vaginal swab and urine samples. The women were tested for HIV at the clinic as part of routine care. Permission to obtain data on HIV status was obtained from the women. Because of the cross-sectional design of the study, the women were not followed up to collect information on pregnancy outcomes.

For the sub-study, $n=221$ urine DNA extracts were available for analysis. Laboratory testing and analyses were performed at the School of Clinical Medicine Laboratory, University of KwaZulu-Natal.

\section{Study procedures}

\section{Data collection}

At enrolment, a face-to-face questionnaire was administered to collect data on the women's demographics (age, level of education and marital status), sexual behaviour (condom use, number of lifetime sex partners, age of sexual debut, partner having other partners, intravaginal practices, cohabitation status and recreational habits such as smoking and consuming alcohol) and clinical information (gestational age, history of previous pregnancies and history of STIs).

\section{Detection of Mycoplasma hominis from urine}

A sensitivity detection assay was performed on the urine DNA extracts. DNA extraction involved a starting volume of $10 \mathrm{ml}$ of urine. A standardised starting volume was used across all samples. The urine was centrifuged for $45 \mathrm{~min}$ at $14000 \times \mathrm{g}$ and the supernatant was discarded. Total DNA was then extracted from recovered sample pellets using the PureLink ${ }^{\mathrm{TM}}$ Microbiome DNA Purification Kit (Thermo Fisher Scientific, United States) in accordance with the manufacturer's instructions. The DNA concentration was measured using a NanoDrop Spectrophotometer (Thermo Fisher Scientific, United States). Resulting DNA concentrations ranged from $3.13 \mathrm{ng} / \mu \mathrm{L}$ to $75.3 \mathrm{ng} / \mu \mathrm{L}$ with $\mathrm{A}_{260} / \mathrm{A}_{280}$ ratios in the range of $0.80-1.91$.

Mycoplasma hominis was detected using the TaqMan Real-time polymerase chain reaction (PCR) (sensitivity) assay (Thermo Fisher Scientific, United States) using commercially available primers and probes specific for M. hominis (Ba04646255_s1). The assays were run on the Quant Studio 5 Real-time PCR detection system (Thermo Fisher Scientific, USA).

Each PCR reaction was performed in a final volume of $5 \mathrm{uL}$ comprising $0.25 \mathrm{uL}$ of FAM-labelled probe/primer mix, $1.25 \mathrm{uL}$ of Fast Start 4x probe master mix (Thermo Fisher, Part No. 4444434), $1.5 \mathrm{uL}$ of template DNA and nuclease-free water.

Non-template and positive controls (TaqMan ${ }^{\mathrm{TM}}$ Vaginal Microbiota Extraction Control; cat no. A32039) were also included. Amplification was performed at $95^{\circ} \mathrm{C}$ for $30 \mathrm{~s}$ followed by 45 cycles comprising denaturation at $95^{\circ} \mathrm{C}$ for 3 $\mathrm{s}$ and annealing at $60^{\circ} \mathrm{C}$ for $30 \mathrm{~s}$. Detection of amplified fluorescent products was carried out at the end of the annealing phase. The raw fluorescence data that included the $\mathrm{C}_{\mathrm{T}}$ mean values were automatically generated using the Quant Studio 5 Real-time PCR system software.

\section{Detection of Mycoplasma genitalium from urine}

Mycoplasma genitalium was detected using the TaqMan Realtime PCR (sensitivity) assay (Thermo Fisher Scientific, United States) using commercially available primers and probes specific for M. hominis (Ba04646249_sl). The reaction and cycling conditions were as per the M. hominis assay conditions.

\section{Detection of bacterial vaginosis, Trichomonas vaginalis and Candida species from vaginal swabs}

The presence of BV, T. vaginalis and Candida species was detected using the $\mathrm{BD}$ Max $^{\mathrm{TM}}$ Vaginal Panel assay (Becton Dickinson, United States) from a single vaginal swab. The assay was performed as per the manufacturer's recommendations. 


\section{Statistical data analyses}

The statistical data analysis was conducted in a freely available Statistical Computing Environment, R software, version 3.6.3 using the RStudio platform. Initially, the population characteristics were described using frequencies stratified by the infection status of the pathogens.

In addition to the frequencies, univariate analysis was used to assess the relationship between each risk factor and the pathogen infection status. The available continuous variable had a skewed distribution calling for a nonparametric test involving a rank-sum test. On the other hand, the categorical risk factors were univariately assessed using the Chi-Square test or the Fisher's exact test in the case of smaller expected frequencies. The significant risk factors were used to fit univariate logistic regressions in order to quantify their relationships with the outcome in terms of odds ratios (ORs). The analysis further considered multiple logistic regression to assess the influence of these univariately significant risk factors in the presence of the other factors. All the tests were conducted at 5\% level of significance.

\section{Ethical considerations}

Ethics approval for this study was granted by the Biomedical Research Ethics Committee (BREC) of the University of KwaZulu-Natal (BE214/17).

\section{Results}

\section{Characteristics of the population according to Mycoplasma hominis status}

The prevalence of $M$. hominis in the study population was $48 \%(106 / 221)$. Table 1 shows the factors in relation to $M$. hominis status. There was no significant association $(p>0.05)$ between the majority of demographic variables and the prevalence of $M$. hominis. Of the $106 \mathrm{M}$. hominis positive women, a small proportion of them, 20.8\% (22/106) had attended college/university when compared to the majority of women $(69.8 \%$ [74/106]) who attended high school. When considering the behavioural factors, it was shown that amongst the $106 \mathrm{M}$. hominis-positive women most women $83.0 \%(88 / 106)$ reported having a regular sex partner when compared to women not reported having a regular sex partner (17\%). A majority of positive women engaged in their first sex at an early age of 15 and 20 years, $72.6 \%(77 / 106)$ followed by delayed sex at $>20$ years of age constituting $21.7 \%(23 / 106)$. The dominant number of lifetime sex partners amongst the $M$. hominis-positive women was 2-4 partners 51.9\% (55/106) compared to just one lifetime sex partner $22.6 \%(24 / 106)$ and $>4$ lifetime sex partners $25.5 \%$ (27/106). The results also showed that $71.7 \%(76 / 106)$ of the M. hominis-positive women did not use a condom at their last sex and 90.6\% (96/106) did not engage in intravaginal practices. Despite the high proportion of women reporting risky behavioural practices, there was no significant association $(p>0.05)$ between most of these potential risk factors and the prevalence of $M$. hominis (Table 1). With respect to the clinical symptoms, it was found that amongst the M. hominis-positive women, almost half did not experience past episodes of abnormal vaginal discharge $50.5 \%(53 / 106)$, which was a significantly $(p=0.037)$ smaller proportion when compared to $64.3 \%(74 / 115)$ who did not experience past episodes of abnormal vaginal discharge amongst the $M$. hominis-negative women. Similarly, at the time of enrolment into the study, a significantly ( $p=0.010)$ smaller proportion 56.6\% (60/106) of women did not experience current abnormal vaginal discharge amongst the M. hominis-positive women compared to $73 \%(84 / 115)$ within the M. hominis-negative women. For the women who tested M. hominis positive, a higher proportion $75.5 \%$ $(80 / 106)$ of them did not experience a previous pre-term delivery. However, the association between pre-term delivery and $M$. hominis infection was at a threshold significance $(p=0.052)$ with more inclination towards insufficient evidence to suggest that the association between pre-term delivery and M. hominis infection indeed exists (Table 1).

\section{Risk factors associated with Mycoplasma hominis infection}

Table 2 shows the risk factors associated with $M$. hominis infection for $p<0.1$. In this univariable analysis, having a current abnormal discharge was two times more likely to test positive for M. hominis (OR: 2.08, 95\% Confidence Interval $[C I]: 1.19-3.67, p=0.011)$. Furthermore, it was shown that having a previous abnormal vaginal discharge increased the risk of testing $M$. hominis positive by $77 \%$ (OR: 1.77 , CI 1.03-3.05, $p=0.038$ ). Finally, this univariate analysis demonstrated that having attained a college level of education reduced the women's risk of being infected by $71 \%$ (OR: 0.29, 95\% CI: 0.08-0.92, $p=0.042$ ). By adjusting these factors amongst themselves, their relationships with prevalent $M$. hominis were found to be statistically insignificant $(p>0.05)$.

\section{Coinfection between Mycoplasma hominis bacterial vaginosis, Trichomonas vaginalis, Candida species and Mycoplasma genitalium}

There was a statistically significant association between M. hominis and BV positivity $(p<0.001)$ (Table 3$)$. That is, amongst the 106 women who tested positive for M. hominis, $66.0 \%$ also tested positive for BV and this was a significantly higher proportion when compared to $27.8 \%(32 / 115) \mathrm{BV}$ positives amongst the $M$. hominis-negative women. Similarly, there was a significant association between M. hominis and M. genitalium positivity $(p=0.006)$. The coinfection rate between M. hominis and M. genitalium was $4.98 \%(11 / 221)$ constituting $10.4 \%(11 / 106)$ of the $M$. hominis-positive women (Table 3). Despite high co-infection rates between $M$. hominis and T. vaginalis $(14.2 \%$ of the $M$. hominis positive) and $M$. hominis and Candida species (59.4\% of the M. hominis positive), these associations were not significant $(p=0.130$ and $p=$ 0.853, respectively) (Table 3). 
TABLE 1a: Characteristics of the study population by Mycoplasma hominis status.

\begin{tabular}{lcccc}
\hline Variable & \multicolumn{3}{c}{ M. hominis } & Overall \\
\cline { 2 - 5 } & Negative $(\boldsymbol{n}=\mathbf{1 1 5})$ & Positive $(\boldsymbol{n}=\mathbf{1 0 6})$ & - \\
\hline Age & - & - & $28.3 \pm 6.04$ & $\mathbf{0 . 4 9 0}$ \\
Mean \pm SD & $28.6 \pm 6.14$ & $28.0 \pm 5.95$ & 21.3 & - \\
CV\% & 21.5 & 21.3 & 27.0 & - \\
Median & 28.0 & 27.0 & $24.0 ; 33.0$ & - \\
Q1; Q3 & $24.0 ; 33.0$ & $18.0-43.0$ & $18.0-43.0$ \\
Min-Max & $18.0-43.0$ & & - \\
\hline
\end{tabular}

TABLE 1b: Characteristics of the study population by Mycoplasma hominis status.

\begin{tabular}{|c|c|c|c|c|c|c|c|}
\hline \multirow[t]{3}{*}{ Variable } & \multicolumn{4}{|c|}{ M. hominis } & \multicolumn{2}{|c|}{ Overall $(n=221)$} & \multirow[t]{3}{*}{$p$-value } \\
\hline & \multicolumn{2}{|c|}{ Negative $(n=115)$} & \multicolumn{2}{|c|}{ Positive $(n=106)$} & \multirow[t]{2}{*}{$n$} & \multirow[t]{2}{*}{$\%$} & \\
\hline & $N$ & $\%$ & $N$ & $\%$ & & & \\
\hline Current abnormal vaginal discharge & - & - & - & - & - & - & 0.01 \\
\hline No & 84 & 73.0 & 60 & 56.6 & 144 & 65.2 & - \\
\hline Yes & 31 & 27.0 & 46 & 43.4 & 77 & 34.8 & - \\
\hline Symptoms of STIs in the past 3 months & - & - & - & - & - & - & 0.08 \\
\hline No & 102 & 88.7 & 85 & 80.2 & 187 & 84.6 & - \\
\hline Yes & 13 & 11.3 & 21 & 19.8 & 34 & 15.4 & - \\
\hline Level of education & - & - & - & - & - & - & 0.061 \\
\hline Primary and below & 5 & 04.3 & 10 & 09.4 & 15 & 06.8 & - \\
\hline High school & 72 & 62.6 & 74 & 69.8 & 146 & 66.1 & - \\
\hline College/University & 38 & 33.0 & 22 & 20.8 & 60 & 27.1 & - \\
\hline Marital status & - & - & - & - & - & - & 0.191 \\
\hline No & 94 & 82.5 & 94 & 88.7 & 188 & 85.5 & - \\
\hline Yes & 20 & 17.5 & 12 & 11.3 & 32 & 14.5 & - \\
\hline Has a regular sexual partner & - & - & - & - & - & - & 0.936 \\
\hline No & 20 & 17.4 & 18 & 17.0 & 38 & 17.2 & - \\
\hline Yes & 95 & 82.6 & 88 & 83.0 & 183 & 82.8 & - \\
\hline Living with sexual partner & - & - & - & - & - & - & - \\
\hline No & 69 & 60.0 & 67 & 63.2 & 136 & 61.5 & - \\
\hline Yes & 46 & 40.0 & 39 & 36.8 & 85 & 38.5 & - \\
\hline Age at first sex & - & - & - & - & - & - & 0.71 \\
\hline$<15$ & 5 & 04.3 & 6 & 05.7 & 11 & 05.0 & - \\
\hline $15-20$ & 89 & 77.4 & 77 & 72.6 & 166 & 75.1 & - \\
\hline$>20$ & 21 & 18.3 & 23 & 21.7 & 44 & 19.9 & - \\
\hline Lifetime number of sexual partners & - & - & - & - & - & - & 0.171 \\
\hline 1 & 37 & 32.2 & 24 & 22.6 & 61 & 27.6 & - \\
\hline 4-Feb & 58 & 50.4 & 55 & 51.9 & 113 & 51.1 & - \\
\hline$>4$ & 20 & 17.4 & 27 & 25.5 & 47 & 21.3 & - \\
\hline Partner has other partners & - & - & - & - & - & - & 0.116 \\
\hline No/Do not know & 86 & 74.8 & 69 & 65.1 & 155 & 70.1 & - \\
\hline Yes & 29 & 25.2 & 37 & 34.9 & 66 & 29.9 & - \\
\hline Condom use & - & - & - & - & - & - & 0.47 \\
\hline Never & 37 & 32.2 & 39 & 36.8 & 76 & 34.4 & - \\
\hline Always & 78 & 67.8 & 67 & 63.2 & 145 & 65.6 & - \\
\hline Condom use at last sexual act & - & - & - & - & - & - & 0.193 \\
\hline No & 73 & 63.5 & - & - & 149 & 67.4 & - \\
\hline Yes & 42 & 36.5 & - & - & 72 & 32.6 & - \\
\hline Smokes & - & - & - & - & - & - & 0.317 \\
\hline No & 112 & 97.4 & - & - & 212 & 95.9 & - \\
\hline Yes & 3 & 02.6 & - & - & 9 & 04.1 & - \\
\hline Consumes alcohol & - & - & - & - & - & - & 0.08 \\
\hline No & 107 & 93.0 & - & - & 198 & 89.6 & - \\
\hline Yes & 8 & 07.0 & - & - & 23 & 10.4 & - \\
\hline Intravaginal practices & - & - & - & - & - & - & 0.973 \\
\hline No & 104 & 90.4 & - & - & 200 & 90.5 & - \\
\hline Yes & 11 & 09.6 & - & - & 21 & 09.5 & - \\
\hline Trimester of pregnancy & - & - & - & - & - & - & 0.898 \\
\hline 1st & 10 & 08.7 & - & - & 21 & 09.5 & - \\
\hline 2nd & 40 & 34.8 & - & - & 75 & 33.9 & - \\
\hline $3 r d$ & 65 & 56.5 & - & - & 125 & 56.6 & - \\
\hline
\end{tabular}

Table $1 \mathrm{~b}$ continues on the next page $\rightarrow$ 
TABLE 1b (Continues...): Characteristics of the study population by Mycoplasma hominis status.

\begin{tabular}{|c|c|c|c|c|c|c|c|}
\hline \multirow[t]{3}{*}{ Variable } & \multicolumn{4}{|c|}{ M. hominis } & \multicolumn{2}{|c|}{ Overall $(n=221)$} & \multirow[t]{3}{*}{$p$-value } \\
\hline & \multicolumn{2}{|c|}{ Negative $(n=115)$} & \multicolumn{2}{|c|}{ Positive $(n=106)$} & \multirow[t]{2}{*}{$n$} & \multirow[t]{2}{*}{$\%$} & \\
\hline & $N$ & $\%$ & $N$ & $\%$ & & & \\
\hline Previous pre-term delivery & - & - & - & - & - & - & 0.052 \\
\hline No & 96 & 83.5 & - & - & 176 & 79.6 & - \\
\hline Yes & 15 & 13.0 & - & - & 40 & 18.1 & - \\
\hline Missing & 4 & 03.5 & - & - & 5 & 02.3 & - \\
\hline No & 80 & 69.6 & - & - & 162 & 73.3 & - \\
\hline Yes & 35 & 30.4 & - & - & 59 & 26.7 & - \\
\hline Past spontaneous abortion & - & - & - & - & - & - & 0.259 \\
\hline No & 107 & 93.0 & - & - & 201 & 91.0 & - \\
\hline Yes & 8 & 07.0 & - & - & 20 & 09.0 & - \\
\hline Previous abnormal vaginal discharge & - & - & - & - & - & - & 0.037 \\
\hline Yes & 41 & 35.7 & - & - & 93 & 42.3 & - \\
\hline Previously treated for STIs & - & - & - & - & - & - & 0.283 \\
\hline No & 69 & 60.0 & - & - & 125 & 56.6 & - \\
\hline Yes & 46 & 40.0 & - & - & 96 & 43.4 & - \\
\hline
\end{tabular}

STIs, sexually transmitted infections.

TABLE 2: Univariate and multiple regression analysis of risk factors associated with Mycoplasma hominis infection.

\begin{tabular}{|c|c|c|c|c|c|c|}
\hline \multirow[t]{2}{*}{ Explanatory } & \multicolumn{3}{|c|}{ OR (Unadjusted) } & \multicolumn{3}{|c|}{ OR (Adjusted) } \\
\hline & OR & $95 \% \mathrm{Cl}$ & $p$-value & OR & $95 \% \mathrm{Cl}$ & $p$-value \\
\hline Current abnormal vaginal discharge & 2.08 & $1.19-3.67$ & 0.011 & 1.58 & $0.77-3.28$ & 0.211 \\
\hline No discharge (Referent) & 1 & - & - & 1 & - & - \\
\hline STI symptoms & 1.94 & $0.93-4.19$ & 0.083 & 0.99 & $0.39-2.52$ & 0.989 \\
\hline No STI symptoms (Referent) & 1 & - & - & 1 & - & - \\
\hline Education (High school) & 0.51 & $0.15-1.52$ & 0.245 & 0.59 & $0.17-1.83$ & 0.374 \\
\hline $\begin{array}{l}\text { Education (Primary school) } \\
\text { (Referent) }\end{array}$ & 1 & - & - & 1 & - & - \\
\hline Consumes alcohol & 2.2 & $0.91-5.70$ & 0.086 & 1.97 & $0.76-5.54$ & 0.175 \\
\hline $\begin{array}{l}\text { Does not consume alcohol } \\
\text { (Referent) }\end{array}$ & 1 & - & - & 1 & - & - \\
\hline Had a previous pre-term baby & 2 & $1.00-4.13$ & 0.054 & 1.61 & $0.77-3.45$ & 0.207 \\
\hline $\begin{array}{l}\text { No previous pre-term delivery } \\
\text { (Referent) }\end{array}$ & 1 & - & - & 1 & - & - \\
\hline Past abnormal vaginal discharge & 1.77 & $1.03-3.05$ & 0.038 & 1.44 & $0.79-2.62$ & 0.231 \\
\hline No past discharge (Referent) & 1 & - & - & 1 & - & - \\
\hline
\end{tabular}

STI, sexually transmitted infection.

TABLE 3: Coinfection between Mycoplasma hominis and genital tract infections

\begin{tabular}{|c|c|c|c|c|c|c|c|}
\hline \multirow[t]{2}{*}{ M. hominis } & \multicolumn{2}{|c|}{ Negative $(N=115)$} & \multicolumn{2}{|c|}{ Positive $(N=106)$} & \multicolumn{2}{|c|}{ Overall $(N=221)$} & \multirow[t]{2}{*}{$p$-value } \\
\hline & $n$ & $\%$ & $N$ & $\%$ & $N$ & $\%$ & \\
\hline Bacterial vaginosis & - & - & - & - & - & - & $<0.001$ \\
\hline Negative & 74 & 64.3 & 29 & 27.4 & 103 & 46.6 & - \\
\hline Positive & 32 & 27.8 & 70 & 66.0 & 102 & 46.2 & - \\
\hline Missing & 9 & 7.8 & 7 & 6.6 & 16 & 7.2 & - \\
\hline Candida species & - & - & - & - & - & - & 0.853 \\
\hline Negative & 47 & 40.9 & 42 & 39.6 & 89 & 40.3 & - \\
\hline Positive & 67 & 58.3 & 63 & 59.4 & 130 & 58.8 & - \\
\hline Missing & 1 & 0.9 & 1 & 0.9 & 2 & 0.9 & - \\
\hline Trichomonas vaginalis & - & - & - & - & - & - & 0.130 \\
\hline Negative & 105 & 91.3 & 90 & 84.9 & 195 & 88.2 & - \\
\hline Positive & 9 & 7.8 & 15 & 14.2 & 24 & 10.9 & - \\
\hline Missing & 1 & 0.9 & 1 & 0.9 & 2 & 0.9 & - \\
\hline Mycoplasma genitalium & - & - & - & - & - & - & 0.006 \\
\hline Negative & 113 & 98.3 & 95 & 89.6 & 208 & 94.1 & - \\
\hline Positive & 2 & 1.7 & 11 & 10.4 & 13 & 5.9 & - \\
\hline
\end{tabular}




\section{Predicting the risk of Mycoplasma hominis infection in the presence of other genital infections}

The results in Table 4 showed that having a prevalent BV infection significantly increased the risk of acquiring M. hominis by 5 -fold in both the unadjusted (OR: 5.19, 95\% CI: 2.75-10.10, $p<0.001$ ) and adjusted analyses (OR: 5.19, 95\% CI: $2.75-10.10, p<0.001)$. The results further revealed that being $M$. genitalium positive doubled the chances of M. hominis infection as compared to having been BV positive. M. genitalium-positive women had an increased risk of M. hominis infection by 12 -fold (OR: $12.28,95 \%$ CI: $2.28-227.76$, $p=0.018$ ) and 10-fold (OR: 9.54, 95\% CI: 1.58-185.73, $p=0.041$ ) in the unadjusted and adjusted analyses, respectively. However, the stepwise regression suggested that Candida species and T. vaginalis were not important in predicting the likelihood of M. hominis infection. That is, without taking Candida species and T. vaginalis into consideration, the refined results still show that BV increased the risk for $M$. hominis infection by close to five-fold (OR: $4.87,95 \%$ CI: 2.61-9.31, $p<0.001$ ) and M. genitalium increased the risk for M. hominis infection by close to nine-fold (OR: 8.90, 95\% CI: 1.52-170.55, $p=0.045)$.

\section{Predicting the risk of bacterial vaginosis infection in the presence of other genital infections}

Table 5 shows that a woman who is M. hominis positive had an increased risk of BV infection by 5 -fold both univariately (OR: 5.37, 95\% CI: 2.96-9.98, $p<0.001$ ) and by controlling for the other genital infections (OR: 5.44, 95\% CI: 2.94-10.39, $p<0.001)$. This confirms that the odds of $M$. hominis infection given BV infection or vice versa are the same (5-fold). Although Candida species infection status was not significantly associated with BV infection, the results showed that it is important to gather data on Candida species alongside that of M. hominis in order to have a better prediction of the BV infection. Unlike for M. hominis, M. genitalium was found to have no leads on the BV infection. However, the T. vaginalis infection status could not indicate the likelihood of infection also for either M. hominis or BV.

\section{Association between Mycoplasma hominis and HIV infection}

For this analysis, the data on HIV status were available for $n=104$ women. A large proportion of the women refused to provide these data. For the 104 women for whom data were available, it was shown that the prevalence of coinfection between HIV and M. hominis was $17.3 \%(11 / 104)$, constituting $45 \%(18 / 40)$ of the M. hominis-positive women. However, there was no statistically significant association between prevalent HIV and prevalent $M$. hominis ( $p=0.975$ ) (Figure 1 ). That is, the prevalence of $M$. hominis infection amongst the HIV-negative and HIV-positive women was similar at approximately $45 \%$.

\section{Discussion}

To the best of our knowledge, this is the first study to provide an estimate on the prevalence of $M$. hominis in pregnant women from the Durban area in South Africa. We report a prevalence estimate of $48 \%$ for $M$. hominis in this study population. Our data are consistent with a previous study conducted in South Africa where Redelinghuys and colleagues also reported high prevalence data for $M$. hominis $(50.7 \%)$ in pregnant women from Gauteng, South Africa. ${ }^{5}$

Going back to the overall study aim, which was to identify risk factors associated with $M$. hominis as well as to determine if M. hominis shared risk factors with other genital infections, the following factors were significantly associated with the

TABLE 4: Risk of acquiring Mycoplasma hominis in the presence of other genital infections.

\begin{tabular}{|c|c|c|c|c|c|c|c|c|c|}
\hline \multirow[t]{2}{*}{ Variable } & \multicolumn{3}{|c|}{ Unadjusted } & \multicolumn{3}{|c|}{ Adjusted } & \multicolumn{3}{|c|}{ Stepwise } \\
\hline & OR & $\mathrm{Cl}$ & $p$-value & OR & $\mathrm{Cl}$ & $p$-value & OR & $\mathrm{Cl}$ & $p$-value \\
\hline BV positive & 5.24 & $2.84-9.92$ & $<0.001$ & 5.19 & $2.75-10.10$ & $<0.001$ & 4.9 & $2.61-9.31$ & $<0.001$ \\
\hline BV negative (Referent) & 1 & - & - & 1 & - & - & - & - & - \\
\hline Candida species positive & 0.93 & $0.52-1.67$ & 0.805 & 1.37 & $0.71-2.71$ & 0.351 & - & - & - \\
\hline Candida species negative (Referent) & 1 & - & - & 1 & - & - & - & - & - \\
\hline T. vaginalis positive & 1.69 & $0.69-4.31$ & 0.254 & 1.99 & $0.73-5.59$ & 0.181 & - & - & - \\
\hline T. vaginalis negative (Referent) & 1 & - & - & 1 & - & - & - & - & - \\
\hline M. genitalium positive & 12.3 & $2.28-227.76$ & 0.018 & 9.54 & $1.58-185.73$ & 0.041 & 8.9 & $1.52-170.55$ & 0.045 \\
\hline M. genitalium negative (Referent) & 1 & - & - & 1 & - & - & - & - & - \\
\hline
\end{tabular}

BV, bacterial vaginosis; T., Trichomonas; M., Mycoplasma.

TABLE 5: Risk of acquiring bacterial vaginosis in the presence of other genital infections.

\begin{tabular}{|c|c|c|c|c|c|c|c|c|c|}
\hline \multirow[t]{2}{*}{ Variable } & \multicolumn{3}{|c|}{ Unadjusted } & \multicolumn{3}{|c|}{ Adjusted } & \multicolumn{3}{|c|}{ Stepwise } \\
\hline & OR & $\mathrm{Cl}$ & $p$-value & OR & $\mathrm{Cl}$ & $p$-value & OR & $\mathrm{Cl}$ & $p$-value \\
\hline Candida species positive & 0.64 & $0.36-1.13$ & 0.127 & 0.62 & $0.33-1.16$ & 0.139 & 0.62 & $0.33-1.15$ & 0.128 \\
\hline Candida species negative (Referent) & 1 & - & - & 1 & - & - & - & - & - \\
\hline T. vaginalis positive & 0.99 & $0.42-2.34$ & 0.979 & 0.70 & $0.27-1.81$ & 0.459 & - & - & - \\
\hline T. vaginalis negative (Referent) & 1 & - & - & 1 & - & - & - & - & - \\
\hline M. hominis positive & 5.37 & $2.96-9.98$ & $<0.001$ & 5.44 & $2.94-10.39$ & $<0.001$ & 5.43 & $2.98-10.15$ & $<0.001$ \\
\hline M. hominis negative (Referent) & 1 & - & - & 1 & - & - & - & - & - \\
\hline M. genitalium positive & 3.16 & $0.91-14.60$ & 0.091 & 1.32 & $0.34-6.49$ & 0.703 & - & - & - \\
\hline M. genitalium negative (Referent) & 1 & - & - & 1 & - & - & - & - & - \\
\hline
\end{tabular}

T., Trichomonas; M., Mycoplasma. 


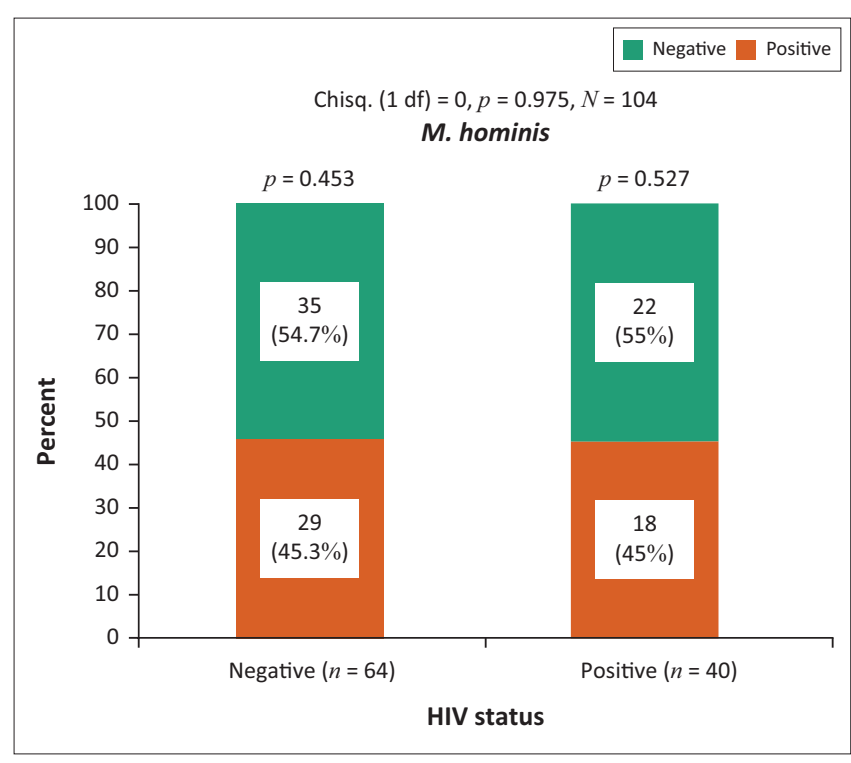

FIGURE 1: Prevalence of Mycoplasma hominis amongst HIV infected and uninfected women.

prevalence of M. hominis: level of education, current abnormal vaginal discharge, past abnormal vaginal discharge and past pre-term delivery. A high proportion of women in this study had attained a high school level of education. There was a borderline significance between this variable and M. hominis status in this study. Previous studies conducted in women from KwaZulu-Natal, South Africa, have shown that women with a lower level of schooling, that is, less than high school, have more prevalent genital infections. ${ }^{15,16,17}$ Abbai et al. showed that women with a lower level of education are at high risk of having multiple STIs $(p=0.034) .{ }^{15}$ Similarly, Naidoo et al. also showed that women with the prevalent STIs reported less than high school education $(p<0.0001) .{ }^{16}$ A significant association between low level of education and prevalence of the viral STI, Herpes simplex virus-2 was also found $(p=0.021){ }^{17}$

In this study, current abnormal vaginal discharge was significantly associated with the prevalence of M. hominis. The majority of women who tested positive did not report symptoms of discharge. A similar observation was reported by Dessai et al. for a population of pregnant women from Durban, where the majority of women who tested positive for Candida reported not having a current abnormal vaginal discharge $(p<0.001) .{ }^{18}$ In another recent study conducted by Mabaso et al., it was shown that the majority of women who tested positive for $T$. vaginalis did not report current symptoms of abnormal vaginal discharge $(p=0.011) .{ }^{19}$ In this study, past abnormal vaginal discharge was also associated with the prevalence of $M$. hominis. The study conducted by Dessai et al. showed a borderline significance $(p=0.06)$ for past discharge and prevalent $T$. vaginalis infections. ${ }^{18}$ Previous studies have shown an association between pre-term deliveries and M. hominis infection. ${ }^{7,12}$ However, the present study did not show a positive association between past history of pre-term delivery and the prevalence of $M$. hominis. An explanation for this could be because of the small overall number of women $(n=40)$ who reported this event. For future association studies, a larger number of women reporting this event may be needed to see a positive association.
In the current study, a univariate and multivariate analysis was performed in order to determine if the significant variables described thus far were truly risk factors associated with $M$. hominis. Reported symptoms of abnormal vaginal discharge were shown to be significantly associated $(p<0.05)$ with prevalent $M$. hominis in the univariate analysis. Women who presented with a current or previous abnormal discharge were two times and $77 \%$ more likely to develop prevalent $M$. hominis. These findings are consistent with another study that reported on the prevalence of genital mycoplasma species, especially $M$. hominis, in patients presenting with vaginal discharge.${ }^{20}$ However, this association was not sustained in the multivariable analysis, indicating that the abnormal vaginal discharge may not be a true risk factor for acquiring $M$. hominis. As shown in this study, there was a high coinfection rate of $M$. hominis with other infections such as $\mathrm{BV}, T$. vaginalis, $M$. genitalium and Candida species. These coinfections could have contributed to the discharge and not necessarily M. hominis.

This is not in keeping with another published study conducted in pregnant women, which showed the association of abnormal vaginal discharge as a true risk factor for another genital pathogen. ${ }^{19}$

The current study also showed that obtaining a tertiary level of education had significantly reduced the women's risk of infection by $71 \%$. This finding is consistent with other previous studies conducted in KwaZulu-Natal. ${ }^{16,17}$ Abbai and co-workers reported a significant association between HSV-2 infection and women who had received a lower level of education. ${ }^{17}$ Similarly, Naidoo et al. associated women receiving lower level education with an increased risk of having a prevalent STI. ${ }^{16}$ However, unlike the findings described by Abbai et al. ${ }^{17}$ and Naidoo et al., ${ }^{16}$ level of education was not significant in the multivariable analysis. Therefore, level of education cannot be deemed as a true low risk factor in this study.

In this study, high coinfection rates were observed for $M$. hominis with BV, Candida, T. vaginalis, M. genitalium and HIV. However, only coinfection rates between M. hominis and BV and M. hominis and M. genitalium were shown to be significant. In the adjusted analysis, BV was shown to significantly increase the risk for $M$. hominis by five-fold. A study conducted by Sanchez-Garcia et al. showed that BV was also significantly associated with an increased risk of positivity for M. hominis (OR: 25.9, $95 \%$ CI: 7.2-93.0; $p=0.001$ ). ${ }^{21}$

According to Panos, the presence of M. genitalium infection was associated with the presence of Mycoplasmataceae family members such as M. hominis and Ureaplasma species, more particularly, Ureaplasma species. ${ }^{22}$ Testing for the presence of Ureaplasma species in the study cohort is a future research direction.

This study was limited in that samples were collected from pregnant women attending a single antenatal facility. However, the hospital from which the women were sampled in this study serves as a central hospital for women from around the Durban area, thereby making the population 
more generalised. A second limitation is the lack of data on pregnancy outcomes in relation to the prevalent infections. Because of the cross-sectional nature of this study, the data were not collected; however, this limitation will be addressed in future studies. Finally, a full dataset on HIV status was not available for this study, because of the refusal to provide the data by the study women and therefore, this study was unable to draw sound conclusions regarding the association between M. hominis and HIV infections.

\section{Conclusion}

To date, there remains uncertainty regarding the role of $M$. hominis as a genital tract pathogen. The current study has now provided evidence from a South African-based pregnant population, indicating that $M$. hominis does not share common predisposing risk factors with that of known genital tract pathogens as well as the causative agents of STIs. Based on these study findings, $M$. hominis cannot be considered a genital tract pathogen. Previous studies have shown a high prevalence of $M$. hominis in the vaginal compartment. ${ }^{23,24}$ Based on the high prevalence of this pathogen in the vaginal micro-environment, future studies that investigate its explicit role in this environment are needed.

\section{Acknowledgements}

The authors would like to acknowledge all study participants and the antenatal clinic staff at the King Edward VIII Hospital, Durban.

\section{Competing interests}

The authors declare that they have no financial or personal relationships that may have inappropriately influenced them in writing this article.

\section{Authors' contributions}

M.N., F.D., R.S., N.M., P.T. and N.S.A. contributed equally to the writing of this article.

\section{Funding information}

The authors gratefully acknowledge the financial support of the National Research Foundation (Grant number 112080: Awarded to Dr Nathlee Abbai).

\section{Data availability}

The data that support the findings of this study are available from the corresponding author, M.N., upon reasonable request.

\section{Disclaimer}

The views and opinions expressed in this article are those of the authors and do not necessarily reflect the official policy or position of any affiliated agency of the authors.

\section{References}

1. World Health Organization. Sexually transmitted infections fact sheet. Geneva: World Health Organization; 2019.

2. Campos GB, Lobao TN, Selis SS, et al. Prevalence of Mycoplasma genitalium and Mycoplasma hominis in urogenital tract of Brazilian women. BMC Infect Dis. 2015;15:60. https://doi.org/10.1186/s12879-015-0792-4

3. Ravel J, Gajer P, Abdo Z, et al. Vaginal microbiome of reproductive - Age women Proc Natl Acad Sci U S A. 2011;108(Suppl 1):4680-4687. https://doi.org/10.1073/ pnas. 1002611107

4. Taylor-Robinson D. Mollicutes in vaginal microbiology: Mycoplasma hominis, Ureaplasma urealyticum, Ureaplasma parvum and Mycoplasma genitalium. Res Microbiol. 2017;168(9-10):875-881. https://doi.org/10.1016/j.resmic.2017.02.009

5. Redelinghuys MJ, Ehlers MM, Dreyer AW, Lombaard HA, Kock, MM. Prevalence of genital mycoplasmas and bacterial vaginosis in pregnant women in Gauteng, genital mycoplasmas and bacterial vaginosis in pregnant women in Gauteng, South Africa. Sex Transm Infect.
sextrans-2013-051184.0495

6. Bayraktar MR, Ozerol IH, Gucluer N, Celik O. Prevalence and antibiotic susceptibility of Mycoplasma hominis and Ureaplasma urealyticum in pregnant women. Int $J$ Infect Dis. 2010;14(2):e90-e95. https://doi.org/10.1016/j.ijid.2009.03.020

7. Cassell GH, Waites KB, Watson HL, Crouse DT, Harasawa R. Ureaplasma urealyticum intrauterine infection: Role in prematurity and disease in newborns. Clin Microbiol Rev. 1993;6(1):69-87. https://doi.org/10.1128/CMR.6.1.69

8. Taylor-Robinson D, Furr PM. Update on sexually transmitted mycoplasmas. Lancet. 1998;351(Suppl 3):12-15. https://doi.org/10.1016/S0140-6736(98)90004-6

9. Daxboeck F, Zitta S, Stadler M, Iro E, Krause R. Mycoplasma hominis and Ureaplasma urealyticum in patients with sterile pyuria. J Infect. 2005;51:54-58. https://doi.org/10.1016/j.jinf.2004.06.010

10. Patai K, Szilágyi G, Hubay M, Szentmáriay IF, Paulin F. Severe endometritis caused by genital mycoplasmas after Caesarean section. J Med Microbiol. 2005;54 1249-1250. https://doi.org/10.1099/jmm.0.05457-0

11. Witt A, Berger A, Gruber CJ, et al. Increased intrauterine frequency of Ureaplasma urealyticum in women with preterm labor and preterm premature rupture of the membranes and subsequent cesarean delivery. Am J Obstet Gynecol. 2005;193(5):1663-1669. https://doi.org/10.1016/j.ajog.2005.03.067

12. Pararas MV, Skevaki CL, Kafetzis DA. Preterm birth due to maternal infection Causative pathogens and modes of prevention. Eur J Clin Microbiol Infect Dis. 2006;25(9):562-569. https://doi.org/10.1007/s10096-006-0190-3

13. Arya OP, Tong CY, Hart CA, et al. Is Mycoplasma hominis a vaginal pathogen? Sex Transm Infect. 2001;77(1):58-62. https://doi.org/10.1136/sti.77.1.58

14. Van der Schee C, Sluiters HJ, Van der Meijden WI, et al. Host and pathogen interaction during vaginal infection by Trichomonas vaginalis and Mycoplasma hominis or Ureaplasma urealyticum. J Microbiol Methods. 2001;45(1):61-67. https://doi.org/10.1016/S0167-7012(01)00224-X

15. Abbai NS, Wand $H$, Ramjee G. Sexually transmitted infections in women participating in a biomedical intervention trial in Durban: Prevalence, coinfections, and risk factors. J Sex Transm Dis. 2013;2013:358402. https://doi.org/10.1155/2013/358402

16. Naidoo S, Wand H, Abbai NS, Ramjee G. High prevalence and incidence of sexually transmitted infections among women living in KwaZulu-Natal, South Africa. AIDS Res Therapy. 2014;11(1):1-7. https://doi.org/10.1186/1742-6405-11-31

17. Abbai NS, Wand H, Ramjee G. Socio-demographic and behavioural characteristics associated with HSV-2 sero-prevalence in high risk women in KwaZulu-Natal. BMC Res Notes. 2015;8(1):1-5. https://doi.org/10.1186/s13104-015-1093-0

18. Dessai F, Nyirenda M, Sebitloane M, Abbai N. Diagnostic evaluation of the BD Affirm VPIII assay as a point-of-care test for the diagnosis of bacterial vaginosis, trichomoniasis and candidiasis. Int J STD AIDS. 2020;31(4):303-311. https://doi. org/10.1177/0956462419895684

19. Mabaso N, Naicker C, Nyirenda M, Abbai N. Prevalence and risk factors for Trichomonas vaginalis infection in pregnant women in South Africa. Int J STD AIDS. 2020;31(4):351-358. https://doi.org/10.1177/0956462420907758

20. Diaz L, Cabrera LE, Fernandez T, et al. Frequency and antimicrobial sensitivity of Ureaplasma urealyticum and Mycoplasma hominis in patients with vaginal discharge. MEDDIC Rev. 2013;15(4):45-47.

21. Sanchez-Garcia EK, Contreras-Paredes A, Martinez-Abundis E, Garcia-Chan D, Lizano M, De la cruz-Hernandez E. Molecular epidemiology of bacterial vaginosis and its association with genital micro-organisms in asymptomatic women. J Med Microbiol. 2019;68(9):1373-1382. https://doi.org/10.1099/jmm.0.001044

22. Panos G. Prevalence studies of $M$. genitalium and other sexually transmitted pathogens in high risk individuals indicate the need for comprehensive investigation of STIs for accurate diagnosis and effective treatment. GERMS. 2018;8(1):8-11. https://doi.org/10.18683/germs.2018.1127

23. Seifoleslami M, Safari A, Khameneie MK. Prevalence of Ureaplasma urealyticum and Mycoplasma hominis in high vaginal swab samples of infertile females. Iran Red Crescent Med J. 2015;17(12):e16823. https://doi.org/10.5812/ircmj.16823

24. Adebamowo SN, Ma B, Zella D, et al. Mycoplasma hominis and Mycoplasma genitalium in the vaginal microbiota and persistent high-risk human papillomavirus infection. Front Public Health. 2017;5:140. https://doi.org/10.3389/fpubh.2017. 00140 